\title{
Enhancing Students Speaking Skills Through Project-Based Learning
}

\author{
Sintya Mutiara We \\ Program Studi Magister Ilmu Linguistik, Universitas Diponegoro, Indonesia \\ sintyamutiara@gmail.com
}

DOI: $10.20884 / 1 . j 1 i .2020 .11 .2 .2931$

\begin{abstract}
Article History:
First Received:

$07 / 04 / 2020$

ABSTRACT

The mastery of English speaking skill is one problem for Indonesian learners

Final Revision: so that it needs one particular treatment to overcome it. This study was aimed

$29 / 10 / 2020$ to investigate if Project-Based Learning (PjBL) was effective to improve speaking skills of the second year of non-English students in one private university in Semarang and how PjBL was able to influence their attitude to speaking. Quantitative and qualitative methods were used. Quasi-experimental

Available online: research design was applied to 53 students. To collect data, instruments

$29 / 12 / 2020$ employed were speaking tests, observations, and interviews. The results showed that the experimental group had a better score compared to the control group. The projects done through PjBL by the experimental group could effectively stimulate and improve their speaking performance shown by the increased means score as amount of 2.59, indicated by the pretest score of 8.74 and the post mean score of 11.33. The range score between the experimental group and the control group was 3.70, indicating that the treatment was effective. Furthermore, Independent Sample T-test showed sig. value (2-tailed) of 0.00, which was lower than 0.05, indicating that there was statistically significant difference between the two groups. The results of the interviews also showed that the students gave positive attitudes towards the implementation of PjBL. Before the treatment the students had low motivation and confidence in speaking. After the 8 week-treatment, the finding showed that they felt enthusiastic and challenged during all the speaking projects. This method was successful to develop the students' motivation and confidence to speak up in English.
\end{abstract}

Keywords: speaking skills; electrical engineering; project-based learning

\section{INTRODUCTION}

The $21^{\text {st }}$ century learning frameworks become the focus of many educators' concern throughout the world these days. Shaping students equipped with knowledge, skills, and technologies is one goal that should always be campaigned in many countries so that those competences can support students for the challenges of the era. 
Speaking skills definitely have a huge contribution to support the implementation of learning skills, such as critical thinking and problem solving, communication, collaboration, and creativity and innovation (Four Cs), as the required skills in the $21^{\text {st }}$ century (NEA:2010). By possessing speaking skills, people can connect their own ability and collaborate with diverse groups and deliver thoughts and problem-solving ideas, develop the ideas, and bring their creativity and innovations into the reality with others. On other words, speaking mastery becomes an urgency to meet the demands of the world.

In its relation to the needs of the global market, Pacific Policy Research Center (2010) states that much success today depends on how good people are in communicating, sharing, and applying information to overcome complex issues. Similarly, Pollack-Wahl (2000) agrees that speaking is one best tool for improving one's career and one biggest factor in determining a student's success or failure. It means that those who have English communication skills will have bigger opportunities in their professional and school world. For example, in a career life, staff with English speaking abilities will get more chances to be trusted to handle projects overseas or deal with other foreign business people. Meanwhile, in an academic life, students with English speaking abilities will not only be able to do some English discussions, presentations, peer-work, but also be able to have a big opportunity to join some international competitions or students exchange programs. The illustrations have proven that English speaking is a part of communication and becomes a need of work life. As stated by Riemer (2002), that oral communication is crucial in the job environment because speaking is inseparable in academic and profession life. Richards and Renandya in Stoller (2002) state that speaking is one of the core elements of communication. It came to conclusion that speaking is one essential part of our daily routines, and it is inevitable in the students and professionals' present and future goals.

Even though speaking skill is important to be mastered now days, it still becomes one of the most difficult skills that language learners have (Bueno, Madrid and Mclaren, 2006). Similarly, Bailey and Savage mention that a combination of many elements in speaking makes English speaking is the most demanding skill of the four skills (1994). Dewi (2016) reveals some conditions which impede students' speaking skills; (1) English is not applied in the learners' daily routines outside, (2) lack of exposure to English in the community and environment, and 3) learning English on campus prioritizes more on the structure and vocabulary, 4) English is not considered as the main subject, but alternative subject, unless there is a requirement to join students' exchange or pursue education abroad. These conditions automatically reduce the students' opportunity to practice their speaking skill. Moreover, students are still faced by some other psychological factors affecting their speaking skills, such as anxiety or shyness, lack of 
confidence, lack of motivation, and fear of mistakes as the factors commonly hinder students from speaking practice (Burns and Joyce in Nunan (1999); Schwartz (2005); and Thornbury (2005). Learning from the experts' perspectives, it can be concluded that speaking is a complex skill integrating many aspects of linguistic and social features which give heavy burdens for Indonesian learners.

The aforementioned problems were also faced by the electrical engineering students of Sultan Agung Islamic University. These students are considered as the young generation who have creative and innovative contributions for the meaningful human civilization. They even have won some national and international robotic and innovation competitions. Therefore, they are expected to be supported by English communication skills since English is an international language which can be the media between the world's needs and their engineering capacity. However, their competence in English language does not facilitate it. Kovalyova, Soboleva, Kerimkulov (2016) gave an evidence that graduate engineers in Russia had a little capability in English communication skill, especially in spoken and written skills which definitely gave impacts on their professional career life. Meanwhile, in Indonesia, the electrical engineering students have a little opportunity to apply their English communication in their daily routines due to the excessive academic-hour. In the classroom, the students also prefer to be passive and silent. Furthermore, engineering is usually assumed as "a masculine area" since engineering is usually occupied by male students. Marcus (1999) states that male students tend to prefer kinesthetic, tactual, visual activities. On other words, any extra active learning activities and peer-work will give more excitement to them in the classroom. Like the class which I observed in this research, all of the students are male. Thus, it needs challenging activities to encourage the students' participation in the classroom and activate their motivation through a flexible and suitable teaching and learning method to integrate speaking skills and the $21^{\text {st }}$ century-skill demands.

Project-Based Learning (PjBL) has been one of mostly-discussed teaching methods these days which is considered to be able to overcome some problems in the classrooms. Goodman (2010) states that PjBL is an instructional approach created for students that enables them to solve challenges through a series of learning activities and real assignments. As defined by Suzie Boss (2015), PjBL is a type of learning method which involves collaborative work in which students learn to deal with real-life problems and challenges. Similarly, Buck Institute for Education (BIE) defines PjBL as a teaching method in which students obtain knowledge and skills by working for an extended period of time to examine and respond to engaging and complex questions, problems, or challenges. From the definitions, it can be seen that the theorists highlight PjBL as a learning 
method allowing students to deal with real-life problems and the ways to solve them. It involves students to think critically, to convey what they think comprehensively, and to make decision accurately based on the experience they face during the experiments.

In relation to $\mathrm{PjBL}$, Thomas (2000) summarizes $\mathrm{PjBL}$ as a model which sets learning through projects. To clarify the various definitions of PjBL, he offers five features of the projects. First, they are curriculum-based, meaning that the themes performed in the projects should be adapted from the curriculum. Second, they are student-driven, meaning that projects are focused on questions or problems that encourage students to encounter the central concepts and principles of a discipline. Students are expected to answer the challenges given through the projects. Third, they are a constructive inquiry. It means that students are pushed to search new information and knowledge to solve the problems that lead them to their new experiences, skills and understandings. Fourth, the projects lead students to their autonomy learning, meaning that teachers serve as a facilitator and a mentor, giving feedback and continuous guidance that allow students to consult with. Besides, teachers also leave students to have their own autonomy and freedom to finish their work. Last, projects emphasize on realism, not school-like learning, meaning that the problems or the questions offered by the teachers tend to be similar as the conditions in a real world so that students feel like facing a reality while conducting the projects.

Some studies have been conducted to reveal the effects of PjBL in influencing the students' speaking skills. Pratiwi (2016) applied PjBL to teach speaking for she applied the PjBL to the eighth graders. Astawa, Artini, and Nitiasih (2017) implemented PjBL to find out its effectiveness to improve the students' speaking and writing skill on junior high school students in Bali. The finding showed that PJBL gave a significant effect on students' English speaking and writing skill. Zare-Bestash and Sarlak (2017) proved that PjBL could improve the students' speaking and writing skills and other external factors, such as motivation and collaboration.

In reference to those previous studies, this research attempts to investigate if Project-Based Learning is effective to enhance speaking skills on the second year of the electrical engineering students of Sultan Agung Islamic University and if the method gives effects on the students' attitude towards speaking.

\section{MATERIALS AND METHOD}

This study employed qualitative and quantitative research design. Quasi-experimental research was used. This research lasted for 2 months and was held in the Faculty of Industrial Technology of Sultan Agung Islamic University. There were 53 electrical engineering students divided into two groups, 26 students for the control group (Class A) and 27 students for the 
experimental group (Class B). In the pretest stage, a set of pictures was used as a medium to elicit the students' vocabulary, pronunciation, grammatical accuracy, fluency, and comprehension, in describing the procedures of making and operating something. The students' speaking was assessed by using the speaking rubrics of Brown (2001). The treatments of PjBL were directed to the experimental group through some speaking projects: the presentations of the product-concepts, the presentations of the really-made products, the video tutorials of the product-making, and the poster-making and poster presentations. After the treatments were completed, the scores were processed through Independent Sample T-test. Next, the students were interviewed in order to find out their perspectives towards PjBL. Any classroom activities during this research were also recorded in the form of field-notes and video-recordings to capture the detailed events of the class, including the detailed impressions, expressions, and attitude of the students during the activities.

\section{RESULTS \& DISCUSSION}

\section{PjBL was Effective to Increase the Students' Speaking Performance}

The answer of the first question was derived from the data of the posttest results which was administered through statistic calculations, as follows:

Table 1. Posttest Results of the Experimental Group and Control Group Statistics

\begin{tabular}{|ll|r|r|r|r|}
\hline & Class & $\mathrm{N}$ & Mean & \multicolumn{1}{c|}{$\begin{array}{c}\text { Std. } \\
\text { Deviation }\end{array}$} & \multicolumn{2}{|c|}{$\begin{array}{c}\text { Std. Error } \\
\text { Mean }\end{array}$} \\
\hline $\begin{array}{l}\text { Gained } \\
\text { Scores }\end{array}$ & $\begin{array}{l}\text { Posttest } \\
\text { Experiment }\end{array}$ & 27 & 15.33 & 2.948 & .567 \\
& $\begin{array}{l}\text { Posttest } \\
\text { Control }\end{array}$ & 26 & 11.62 & 3.522 & .691 \\
\hline
\end{tabular}

The result shows that the experimental group had mean scores of 15.33 and the control group had mean scores of 11.62. From the result, it can be seen that the performance of both groups was significantly different. The mean scores of the experimental group was higher than the mean scores of the control group. This indicates that the speaking skills of the experimental group could improve after the treatment of $\mathrm{PjBL}$. 
Besides the comparison of the posttest scores from the two groups, the pretest scores also showed a big improvement by the experimental group. In the pretest, the group received mean scores of 8.74. It can be seen that the scores increased 6.59 showing that a good result.

Table 2. The Results of Independent Sample T-test, Independent Samples Test

\begin{tabular}{|c|c|c|c|c|c|c|c|c|c|c|}
\hline & & \multicolumn{2}{|c|}{$\begin{array}{l}\text { Levene's Test } \\
\text { for Equality } \\
\text { of Variances }\end{array}$} & \multicolumn{7}{|c|}{ t-test for Equality of Means } \\
\hline & & \multirow[b]{2}{*}{$\mathrm{F}$} & \multirow[b]{2}{*}{ Sig. } & \multirow[b]{2}{*}{$\mathrm{t}$} & \multirow[b]{2}{*}{ df } & \multirow{2}{*}{$\begin{array}{l}\text { Sig. }(2- \\
\text { tailed) }\end{array}$} & \multirow{2}{*}{$\begin{array}{c}\text { Mean } \\
\text { Difference }\end{array}$} & \multirow{2}{*}{$\begin{array}{l}\text { Std. Error } \\
\text { Difference }\end{array}$} & \multicolumn{2}{|c|}{$\begin{array}{l}\text { 95\% Confidence Interval of the } \\
\text { Difference }\end{array}$} \\
\hline & & & & & & & & & Lower & Upper \\
\hline $\begin{array}{l}\text { Gained } \\
\text { Scores }\end{array}$ & $\begin{array}{l}\text { Equal } \\
\text { variances } \\
\text { assumed }\end{array}$ & .555 & .460 & 4.173 & 51 & .000 & 3.718 & .891 & 1.929 & 5.507 \\
\hline
\end{tabular}

The table of Independent Sample T-test shows $t$-value $(\mathrm{t}=4.173)$ and the degree of freedom $(d f=51)$. The two-tailed test (Sig. (2-tailed)) is 0.00 as the probability value (P value). Since the significance value shows 0.00 , which is less than $0.05(\mathrm{p}<5)$, the null hypothesis $\left(\mathrm{H}_{0}\right)$ implying that there is no different effect is rejected, and the alternative hypothesis $\left(\mathrm{H}_{1}\right)$ is accepted. Therefore, it can be said that the difference of the mean scores of the Experimental Group and Control Group are statistically significant. This result represents a high improvement on the posttest scores of Experimental Group as a group which got a treatment with PjBL compared to Control Group which did not get a treatment with PjBL.

Based on the statistic results, English speaking presentations and practices continuously could gradually enhance the students' speaking abilities. Even though they found some difficulties in the beginning, such as feeling shy, scared, or not confident to speak up in English, they finally could solve those problems. They overcame their fear and shyness by making the speaking performance as habits. They also prepared themselves by memorizing the steps of presentations and anticipating questions in the question and answer sessions before the show even though they still needed to face real questions from the other groups during the show. Besides, the projects were designed that the students did not only practice their speaking at campus during the presentation times, but they also practiced their English while making the video-tutorials of the product making, even when the teacher was not with them. They also recorded their activities 
while having discussions with their groups. The students did not only prepare what they needed to say, what steps they needed to do, how they made the products in the presentation, but they also had to perform spontaneous English practices during discussions and question and answer sessions among their group members.

In conducting $\mathrm{PjBL}$, the students from the experimental group were initially faced by three problems to solve: (1) what products will you make to save our environment? (2) how do you make the products? and (3) how do you convince people about your products? From these three problems, the students who worked in 6 groups, finally accomplished. They named their products: A Clap Switch, A Muffler Handphone Charger, A Fertility Soil Tester, A Mosquito Battery Repellant, A Plastic Wind Power Plants, and A Bottle Cleaner. These products answered the first and second problems. The third problem was answered by making posters about their products and uploading their products in Facebook in order to show their work to people and give a campaign that their products could help and give advantages to people.

\section{The PjBL Influences the Students'Speaking Performance}

To answer the second question of this research, the results of interview and observations were presented. In the interview, each student was asked about his experience in doing the speaking projects. All of them stated that $\mathrm{PjBL}$ gave impacts in developing their speaking skills. The results are as follows:

\section{Grammar}

"When doing an English presentation in front of the class and making a campaign video, we learned how to use grammar correctly. These activities really increased out English learning outcome. We did feel our English improved." (RAA5)

Based on the student's statement, PjBL helped him to develop his grammatical knowledge. The projects allowed him to check and recheck his saying while he was recording his performance several times. This is relevant to Brown (2003) that activities in the form of storytelling, discussion, question and answer are effective to make students' speaking skills better. The activities in $\mathrm{PjBL}$ such as recordings, presentations, discussions, and question-answer sessions in this study provided the students chances to use their language. Besides, the teacher acted as a facilitator so that students felt their autonomy in conducting their tasks. However, the teacher also corrected the students' work after they finished their performance. 


\section{Vocabulary}

"It improved our vocabulary, especially in electrical engineering terms, as engineering has particular terms." (MH3)

From the statement, the student felt the benefits of $\mathrm{PjBL}$ in enriching his vocabulary. It definitely worked since during the practices, the student himself prepared the words he was using for his presentations, such as the vocabulary related to materials, steps of procedures so that he could describe his product and explain how the product was made. Besides, he had to answer his friends' questions in the question and answer sessions that needed simultaneous responses. This is supported by Zare-Behtash and Sarlak (2017) that PjBL offers teamwork so that it facilitates selfcorrection and peer-correction among the team members.

\section{Pronunciation}

"I was happy to learn how to pronunciation for some words I chose for my presentation." (MF06)

The student thought that PjBL made him feel joyful during pronunciation learning. He learned the pronunciation of the words from the dictionary and exposure he got during the speaking practices with his friends. The more he heard the words, the more he observed and absorbed the correct pronunciation.

\section{Comprehension}

"I basically understood what was taught in these activities. The materials were about describing things that had been taught by the teacher before. We also had learned procedure text material. Then we were assigned to apply those materials in our projects." (MU25)

The student statement implied that he could understand the topics given by the teacher by PjBL. He could get the point about how to describe a procedure of making things or operating things through the projects. He also learned what the functions of the expressions through the speaking projects. Related to this, Saville-Troike (2006) propose that the success of language learning is mainly affected by social experience: the quality and quality of input and interaction. It means that the more the students get opportunity to be exposed with the target language input and output in the form of interaction, the more the students can achieve the target of learning. These projects enabled more opportunity to practice inside and outside the classroom since it emphasized on the real-life activities. It means that it did not merely give drilling and grammar focus, but it also offered more comprehensive language aspects. 


\section{Fluency}

"In my opinion, PBL was very effective to improve our English skill because we did not feel we were studying, but the English words just came out subconsciously. We could ask and answer questions when we were having a question and answer question." (MU01)

The student said that PjBL allowed them to practice more often and more regularly that it made him easier to apply his English. This is supported by Yiying (2015) that implementing PjBL for a series of projects allows more activities for students to do some work which enable them to practice their language. It means the students will have more time to practice his fluency in English language learning.

\section{Confidence}

"I am more confident to speak in English. I used to be so afraid of delivering my thoughts in English, but I am more comfortable to convey my ideas now." (WJ03)

From the student' statement, his improved confidence affected him to develop his speaking ability. He used to have a fear of making grammatical errors, incorrect vocabulary or pronunciation. However, through the speaking projects, he felt more confident since he did not only do the work individually, but he also did it in team. His peers supported and motivated them to do better since each other would correct each other. This kind of input also enriched their vocabulary, grammar, and pronunciation. It is definitely supported by Krashen that the successfulness of language learning is influenced by three factors: motivation, confidence, and anxiety (1982).

\section{Shyness}

"PjBL was useful to reduce our shy feeling because we often practiced our English in front of the class. We were also pushed to perform. Yet, we felt more confident since when we answered the questions from the audience, we thought together with my friends." (AR20)

The student' response indicates that he could solve his shyness since he practiced his speaking regularly. He was gradually able to get rid of his nervousness while performing in front of class. $\mathrm{PjBL}$ offers a solution that it facilitates self-correction and peer-correction so that there are no superiors and inferiors in the teamwork. This idea is approved by Zare-Behtash and Sarlak (2017) that each student can learn from peers that this activity can reduce their anxiety. In this 
study, the students willingly shared their knowledge related to speaking, vocabulary, or pronunciation for giving their best in reaching their work goal.

\section{Self-Centeredness}

"When we were asked to do the tasks, it should have come from our own will. The lecturer was guiding us, but our own motivation was the key of the success." (HS12)

According to the student' statement, he considered the projects given were his learning media to success. He realized that he should not depend on his teacher about his success but his own motivation. During the projects, he had to search the sources relating to his product, from internet, previous research, and papers. He had to do some trials and errors so that the product could be used. He also needed to ask his seniors and friends to find out if the components of the products worked and how to make it work. This is relevant to Harmer (2001) that project work allows the teachers to be a participant as well. It means the teachers can get involved in any communicative tasks, such as the participant during the presentation so that they can ask the students about the products. However, the teachers give the students more opportunities to discuss any topics and problems with their peers and groups first before the teachers give the feedback. By this condition, the students will be more active and willing to speak up to peers in the classroom activities. In this study, feedback was always given by the teacher whenever the question and answer session was finished so that the students could take the lessons for the next presentations. This method was effective since the students did not feel intimidated for always being corrected during their performance.

\section{Activeness}

"Yes, PJBL improved our English skill. It was because when we were having a presentation for our product, we needed to arrange a title, materials, components, procedures, strengths and weaknesses, and gave an explanation to audience in a good structure and a good manner. By the ability of managing these points, we were taught to understand, to describe, and to get inspired by presentations that had been discussed before." (RS23)

The student stated that $\mathrm{PjBL}$ influenced him to be active in the classroom activities. He felt more relaxed in doing the assignment since he trusted his teacher as his guide in the language learning, not as a dictator and corrector. The teacher gave responses and feedback after their performance. Supported by Harmer (2001) who states that project work does not only arrange students' participation, but it also allows the teachers to be a participant as well. It means the teachers can get involved in any communicative tasks, such as the participant during the 
presentation so that they can ask the students about the products. However, the teachers give the students more opportunities to discuss any topics and problems with their peers and groups first before the teachers give the feedback. By this condition, the students will be more active and willing to speak up to peers in the classroom activities.

\section{Motivation}

"I have ever learned "The Principles of Three SA" (Terpaksa, Dipaksa, Terbiasa) meaning "3 Principles of SA" (Being Urged, Being Forced, and Being Accustomed)." It really works in improving our skill in anything, including in learning English language." (MU14)

Based on the student' saying, it can be seen that PjBL developed his motivation in learning English speaking skills. He himself believed that motivation is the first thing to give an impact in his success. On other words, he had intrinsic and extrinsic motivation. Intrinsic motivation is supported by the autonomous feeling, relatedness, and competence, accompanied by a sense of interest and value (Ryan and Deci:2000). While extrinsic motivation is shown by the atmospheres that were built in his classroom. The student said that by seeing his friends performing, he became more enthusiastic in improving his English speaking skills. The condition of the classroom where the teacher gave the students freedom and autonomy also made him more encouraged to explore, handle, and relate the content of the lessons in their real life (Weimer, 2002). This is relevant to Weimer's opinion of constructivism that students should build knowledge by not depending only to their teacher. They must learn by doing so that they can take lessons from the experiences and failures they face.

\section{Students' interests}

"Through PjBL, the class was challenging, Mam. Since we are from engineering, we can apply it in our daily routines through English.” (WJ01)

The student said that the method was exciting that made him motivated in participating in every project since the projects were so closed with his daily life. In this case, the student comes from electrical engineering who deals with electrical things and innovations or creations. In the projects, the student was asked to create some electrical products which could save environment. Therefore, the student felt challenged to answer the problems given by the teacher and eager of solving problems appearing during the processes since what he was doing would give benefits to his daily life. This relates to what is said by Kafai and Resnick (1996), they say that students can 
present what they have learned through some real projects: plays, multimedia presentations, poems. It means that the students will not only learn theories but also apply the theories in the real life.

English in the $21^{\text {st }}$ century

"PBL could improve our English. By the existence of technology development in this era, if we cannot support ourselves with English language, we will be left behind. We will not be able to follow the development in this world." (AM3)

In the interview, there was also a question related to the importance of English in the $21^{\text {st }}$ century. According to the student' opinion, English is crucial in this era and he agreed that English should be mastered by students in order to survive in the world's competition.

\section{CONCLUSION}

The research reveals that PjBL was a method which could improve students English speaking skills effectively. The students could think actively encouraged by the projects and apply it through English communication with their peers. The students also felt enthusiastic while participating in any presentations and discussions. They also felt challenged for answering the problems given the teachers. Besides, they also realized that English speaking skills were beneficial for their academic and future career so that they were committed to practice more seriously.

Now that PjBL was effectively proven to foster the students' speaking skills and it also gave effects on any other aspects, such as developing the students' enthusiasm, interests, engagement, motivation, and teamwork among peers, it is possible that the result of this research can be used as a reference for the following research, related to $\mathrm{PjBL}$ and the required learning skills in the $21^{\text {st }}$ century, the Four Cs (Critical thinking and problem solving), Communication, Collaboration, and Creativity and Innovation, in the different area of teaching.

However, this study also contained some weaknesses. This study consumed eight weeks since the projects took a lot of time to finish and needed some processes of trial and error. The students also needed to allocate some money to buy the components for their products. The projects also demanded high energy, commitment, discipline, and time-management that if they could not fulfill it, they failed their own projects. 


\section{REFERENCES}

Astawa, N. L. P.N.S., Artini, L. P., and Nitiasih, P. K. (2017). Project-based Learning Activities and EFL Students' Productive Skills in English. Journal of Language Testing and Research, Vol.8, No. 6, pp. 1147-1155, November 2017.DOI:http//dx.doi.org/10.17507/jltr.0806.16.

Bayley, K.M. and Savage, L. (1994). New Ways in Teaching Speaking. Alexandria, VA: Teacher of English to Speakers of Other Languages.

Boss, S. (2015). Implementing Project-Based Learning. United States of America: Solution Tree Press.

Brown, H. D. (2001). Teaching by Principles: An Interactive Approach to Language Pedagogy Second Edition. White Plains, NY: Addison-Wesley.

Brown , H. D. (2003). Language Assessment: Principles and Classroom Practices. White Plains, New York: Pearson Education.

Buck Institute for Education (BIE). (2012). What is PBL? http://www.bie.org/about/what_is_pbl.

Bueno, A., Madrid, D. and McLaren, N. (2006). TEFL in Secondary Education. Granada: Editorial Universidad de Granada.

Dewi, K. (2016). The Correlation of SMA Students' Habit in Watching Movie and Their Speaking Skill. MENDIDIK: Jurnal Kajian Pendidikan dan Pengajaran, 2(2), 112-118.

Goodman, B. (2010). Project-Based Learning. http://www.fsmilitary.org.

Harmer, J. (1998). How to Teach English. England: Pearson Education Limited.

Harmer, J. (2001). Practice of English Language Teaching. Harlow: Pearson Education Limited.

Kafai, Y. B., and Resnick, M. (1996). Constructionism in Practice. Mahwah, NJ: Lawrence Erlbaum.

Kovalyova, Y., Soboleva A.V., \& Kerimkulov A.T. (2016). Project Based Learning in Teaching Communication Skills in English as a Foreign Language to Engineering Students. International Journal of Emerging Technologies in Learning (iJET) - Volume 11, Issue 4. DOI 10.399/ijet.v11i04.5416.

Krashen, S. (1982). Principles and Practice in Second Language Acquisition. University of California: Pergamon Press Inc.

Marcus, L. (1999). A Comparison of Selected Male and Female Students' Learning Styles. New York: Oxford University Press.

National Education Association. (2010). Preparing $21^{\text {st }}$ Century Students for a Global Society an Educator's Guide to the "Four Cs". http://www.nea.org/assets/docs/A-Guide-toFour-Cs.pdf.

Nunan, D. (1999). Second Language Teaching and Learning. Boston: Heinle \& Heinle Publishers.

Pacific Policy Research Center. (2010). 21 ${ }^{\text {st }}$ Century Skills for Students and Teachers. Honolulu: Kamehameha Schools, Research \& Evaluation Division. 
Polack-Wahl, J.A. (2000). It is Time to Stand up and Communicate. In Proc. 30 ASEE/IEEE Frontiers in Educ. Conf., Kansas City, USA, F1G-16-F1G21.

Pratiwi, N. 2016. Project-Based Learning to Enhance Junior High School Students' Speaking Skill and Their Motivation in Learning the Speaking Skill. Master Thesis.

Riemer, M.J. (2006). Communication Skills for the $21^{\text {st }}$ Century Engineer. Global J. of Engng. Educ., Vol.11, No.1 Published in Australia

Richards, J. C. and Willy. A. Renandya. (2002). Methodology in Language Teaching: An Anthology of Current Practice. Cambridge: Cambridge University Press.

Ryan, R. M., and Deci, E.L. (2000). Self-Determination and Facilitation of Intrinsic Motivation, Social Development, and Well-Being. American Psychologist, DOI: 10.1037/0003-066X.55.1.68.

Saville-Troike, M. 2006. Social Contexts of Second Language Acquisition. In Introducing Second Language Acquisition (99-132). Cambridge, UK: Cambridge University Press.

Schwartz, R. L. (2005). Taking A Closer Look at Struggling ESOL Learners. http://www.ncsall.net/?id=994

Stoller, F. L. (2002). Project Work: A Means to Promote Language and Content. In Jack, C. Richards \& Willy, A. Renandya (Eds.) Methodology in Language Teaching: An Anthology of Current Practice (Pp. 107-120). Cambridge: Cambridge University Press.

Thomas, J. W. (2000). A Review of Research on Project-Based Learning. http://www.bie.org/index.php/site/RE/pbl_research/29

Thornbury, S. (2005). How to Teach Speaking. Essex: Pearson Education Limited.

Yiying, Z. (2015). Project-Based Learning in Chinese College English Listening and Speaking Course: From Theory to Practice. Canadian Social Science. Vol.11 No 9. pp. 40-44. DOI:10.3968/7532.ISSN 1712-8056.

Zare-Behtash, E., \& Sarlak, T. (2017). The Effect of Project Based Learning (PBL) on the Components of Speaking Ability of Iranian EFL Beginner Learners. Journal of Applied Linguistics and Language Research Volume 4, Issue 3, 2017, pp. 119-130. Available online at www.jallr.com.ISSN: 2376-760X. 